\title{
PERANAN PEREMPUAN DALAM MENGEMBANGKAN PELAYANAN DI GEREJA KEMAH INJIL INDONESIA DAERAH III NABIRE PAPUA
}

\author{
Frans Geras \\ sttjaffraymakassar@yahoo.co.id
}

Elisabeth Selfina - Ronda

\begin{abstract}
ABSTRAK
Frans Geras, Peranan Perempuan Dalam Mengembangkan Pelayanan Di Gereja Kemah Injil Indonesia Daerah III Nabire Papua .

Setiap tindakan yang kita lakukan pasti memiliki tujuan yang ingin di capai. Adapun tujuan yang ingin di capai dari penulisan karya ilmiah ini adalah sebagai berikut. Pertama, untuk menjelaskan sejauh mana peranan perempuan dalam mengembangkan pelayanan di gereja pada umumnya dan khususnya di GKII Daerah Nabire. Kedua, mengupayakan strategi pelayanan dalam meningkatkan peranan perempuan dalam mengembangkan pelayanan di gereja.

Untuk mendapatkan data dan informasi yang berhubungan dengan penulisan karya ilmiah ini, maka penulis menggunakan beberapa metode sebagai berikut: Pertama, mengadakan observasi atau pengamatan lapangan, adalah cara pengambilan data dengan menggunakan mata tanpa ada pertolongan alat standar untuk keperluan tersebut". Kedua, mengedarkan angket kepada beberapa anggota jemaat GKII Daerah III Nabire Papua. Ketiga, mengadakan wawancara dengan beberapa anggota jemaat dan juga gembala dari beberapa gereja GKII Daerah III Nabire Papua. Kempat, riset perpustakaan dengan mengumpulkan data atau informasi dari buku-buku yang ada di perpustakaan Sekolah Tinggi Teologia Jaffray Makassar serta internet.

Hasil yang didapat dari penulisan karya ilmiah ini adalah: tidak semua gereja atau jemaat yang ada di gereja GKII Daerah III Nabire, menolak perempuan untuk terlibat dalam pelayanan di gereja, hanya ada di gereja tertentu saja yang menolak perempuan untuk melayani di gereja.
\end{abstract}

Kata kunci: Perempuan, Pelayanan, GKII Daerah III, Nabire-Papua

\footnotetext{
${ }^{1}$ Moh. Nazir, Metode Penelitian, (Jakarta : Ghalia Indonesia, 1988), 212
} 


\section{PENDAHULUAN}

\section{Latar Belakang Masalah}

Di tengah dunia yang semakin mengglobalisasi dan penuh dengan berbagai kemajuan di berbagai bidang, tentunya hal ini tidak terlepas dari adanya peran perempuan yang juga turut mengambil bagian dalam membangun serta mengupayakan kemajuan suatu bangsa atau organisasi itu sendiri. Hal ini tidak bisa lagi kita pungkiri atau menutup mata. Kita tidak bisa mengucilkan perempuan atau menomor duakan perempuan di banding pria. Di Indonesia ada terdapat beberapa tokoh perempuan yang memiliki peran dalam pembangunan dan kemajuan bangsa atau organisasi yang ada di negara ini, dan mereka di kenal sebagai pahlawan nasional dan tokoh pembangunan, diantaranya ibu R.A. Kartini, ibu S. Kartowijoyo, ibu Herlina, ibu Maria Ulfa Subadio, ibu S.K Trimurti.

Dalam buku Peranan Wanita Indonesia Dalam Pembangunan, "Soeharto berpendapat bahwa pembangunan bangsa yang serba murka dan menyeluruh itu pasti sulit dapat berhasil, sekiranya setengah dari masyarakat yang terdiri dari kaum wanita tidak turut aktif didalamnya. Peranan kaum wanita dalam pembangunan ini semakin penting artinya, karena kaum wanita khususnya kaum ibu adalah pendidik dari anak-anak yang akan menjadi pelaku-pelaku pembangunan." 2

Begitu juga dengan kehidupan umat Israel, jika kita melihat dalam Alkitab maka di sana kita akan menemukan beberapa tokoh perempuan yang juga mempunyai peran dalam kehidupan bangsa Israel diantaranya, Debora yang berperan sebagai hakim dan juga nabiah yang berhasil membawa bangsa Israel berperang melawan Sisera dan memenangkan perang itu (Hakim-hakim 4:1-24). ${ }^{3}$ Demikian juga dengan Ester yang menjadi ratu dan berhasil menjadi penghubung antara raja dan umat Israel serta menjadi penyelamat bagi bangsa Israel dari ancaman atau rancangan jahat Haman (Ester 8:1-17). Melalui tokoh ini sangatlah jelas bahwa Allah tidak melihat jenis kelamin dalam menentukan atau memilih seorang pemimpin untuk memimpin umatnya. Demikian juga dengan budaya atau orang Israel, di sini tidak terlihat adanya pertentangan terhadap peranan dari tokoh-tokoh

\footnotetext{
${ }^{2}$ Peranan Wanita Indonesia dalam Pembangunan (s.1): PT Norindo Pratama Studio Production (s.a), 13.

${ }^{3}$ Alkitab (Jakarta, Lembaga Alkitab Indonesia, 2006).
} 
perempuan yang terlibat dalam memimpin bangsa mereka (umat Israel).

Dalam kitab 1 Samuel 16 di sana menceritakan kisah tentang pemilihan seorang raja untuk menggantikan Saul. Allah memerintakan Samuel untuk mengurapi seorang raja yang sudah Ia tetapkan yaitu Daud, akan tetapi dalam proses pemilihan itu Samuel diperhadapkan pada sebuah pilihan yang didasarkan pada pemikirannya sendiri yaitu bahwa untuk memilih seorang raja haruslah berperawakan yang baik, hal ini sangatlah bertolak belakang dengan pemikiran Allah sehingga muncul ungkapan dari Allah dalam 1 Samuel 16:7 b yaitu "bukan yang dilihat manusia yang dilihat Allah; manusia melihat apa yang didepan mata, tetapi Allah melihat hati". Inilah yang harus menjadi prinsip utama dari kita bahwa menjadi pemimpin atau pelayan Tuhan, bukanlah karena pilihan manusia tetapi karena pilihan Allah, "karena hanya Allah yang dapat memilih dengan tepat". ${ }^{4}$

Sangatlah penting bagi seorang pemimpin atau gembala untuk mengerti betapa pentingnya kehadiran perempuan dalam persekutuan jemaat di gereja terlebih lagi dalam pelayanan. Hal ini disebabkan karena tidak semua bentuk pelayanan dalam gereja dapat di kerjakan oleh para kaum laki-laki. Inilah tujuan dari Allah untuk menciptakan perempuan, agar perempuan dapat menjadi penolong bagi kaum pria dalam menjalani kehidupan pelayanan di bumi ini (Kej 2:18, TUHAN Allah berfirman: "Tidak baik, kalau manusia itu seorang diri saja. Aku akan menjadikan penolong baginya, yang sepadan dengan dia). Sedangkan dalam kejadian 1:27-28 di sana di katakan juga, bahwa ketika Allah menciptakan manusia, Allah menciptakan manusia itu sama, menurut gambar dan rupa Allah dan Allah memberikan kuasa kepada manusia baik Adam maupun Hawa untuk berkuasa atas segala ciptaannya. Di sini jelas terlihat bahwa tidak ada perbedaan dipandangan Allah, untuk membedakan antara laki-laki maupun perempuan, atau Allah lebih mengutamakan laki-laki di banding perempuan. Dalam arti bahwa baik laki-laki maupun perempuan memiliki tanggung jawab yang sama dalam pandangan Allah untuk menatalayani semua yang di berikan Allah kepada manusia itu sendiri. Karena itu sangatlah di perlukan adanya saling pengertian dalam pembagian peran antara laki-laki dan perempuan dalam pelayanan

${ }^{4}$ James Montogomery Boice, Dapatkah Aku dipakai Allah (Bandung : Kalam Hidup, 1982), 108 
sehingga kuasa yang diberikan Allah semaksimal mungkin untuk dapat digunakan demi kemulian Allah. ${ }^{5}$

Berdasarkan pandangan di atas dan pengamatan serta pengalaman dari penulis selama ber-KKL di Gereja GKII jemaat Bethesda Nabire Papua, maka perlunya di berikan kesempatan pelayanan secara nyata dan terbuka, kepada kaum perempuan di gereja, khususnya di gereja Kemah Injil Indonesia Daerah III Nabire Papua sehingga para kaum perempuan juga dapat melayani dengan tanpa memiliki tekanan dari para pemimpin gereja GKII Daerah III Nabire, demi mengembangkan karunia yang Allah berikan bagi mereka untuk kemajuan pelayanan gereja. Hal ini di karenakan di beberapa Gereja Kemah Injil Indonesia Daerah III Nabire Papua, perempuan tidak di ijinkan untuk terlibat atau mengambil bagian dalam pelayanan gereja, baik sebagai pemimpin pujian (WL), majelis, atau gembala sidang di gereja. Para kaum perempuan hanya menjadi jemaat biasa yang tidak terlibat atau mengambil bagian dalam pelayanan di jemaat. Para kaum perempuan datang ke gereja hanya untuk mengikuti ibadah, selebihnya para kaum laki-lakilah yang lebih mendominasi dalam semua aspek pelayanan di gereja.

Dengan adanya masalah diatas, maka penulis terbeban untuk mengembangkan gagasan atau buah pikiran dalam karya Ilmiah ini dengan judul "PERANAN PEREMPUAN DALAM MENGEMBANGKAN PELAYANAN DI GEREJA KEMAH INJIL INDONESIA DAERAH III NABIRE PAPUA".

\section{Pokok Masalah}

Berdasarkan latar belakang masalah diatas, maka yang menjadi pokok masalah yang akan dibahas dalam penulisan karya ilmiah ini adalah:

Pertama, Apakah kaum perempuan berperan dalam mengembangkan pelayanan di gereja, secara khusus di GKII daerah III Nabire Papua?

Kedua, bagaimana peran kaum perempuan, secara khususnya di gereja GKII Daerah III Nabire Papua.

\footnotetext{
${ }^{5}$ Kapahang - Kaunang. Perempuan: Pemahaman Teologis Tentang Perempuan Dalam Konteks Budaya MInahasa, (Jakarta: Bpk Gunung Mulia, 1993), 19
} 


\section{Tujuan Penulisan}

Setiap tindakan yang kita lakukan pasti memiliki tujuan yang ingin di capai. Adapun tujuan yang ingin di capai dari penulisan karya ilmiah ini adalah sebagai berikut.

Pertama, untuk menjelaskan sejauh mana peranan perempuan dalam mengembangkan pelayanan di gereja pada umumnya dan khususnya di GKII Daerah Nabire.

Kedua, mengupayakan strategi pelayanan dalam meningkatkan peranan perempuan dalam mengembangkan pelayanan di gereja.

\section{Manfaat Penulisan}

Pertama, agar perempuan dapat turut berperan aktif dalam setiap pelayanan di gereja, sebagaimana para kaum laki-laki.

Kedua, agar perempuan dapat mengenal serta mengembangkan karunia yang Allah berikan bagi mereka.

Ketiga, sebagai bahan masukan atau kontribusi kepada pimpinan dan jemaat gereja GKII daerah III Nabire untuk memperoleh pengetahuan yang jelas sehubungan dengan peranan perempuan dalam mengembangkan pelayanan di gereja

Keempat, karya ilmiah ini akan menjadi sebuah pegangan bagi penulis secara pribadi, dan juga untuk memenuhi salah satu syarat dalam menyelesaikan Studi Strata Satu (S-1) di Sekolah Tinggi Theologia Jaffray.

\section{Metode Penelitian}

Untuk mendapatkan data dan informasi yang berhubungan dengan penulisan karya ilmiah ini, maka penulis menggunakan beberapa metode sebagai berikut:

Pertama, mengadakan observasi atau pengamatan lapangan, yaitu di Gereja Kemah Injil Indonesia Daerah III Nabire Papua. "Observasi adalah cara pengambilan data dengan menggunakan mata tanpa ada pertolongan alat standar untuk keperluan tersebut". 6

Kedua, mengedarkan angket kepada beberapa anggota jemaat GKII Daerah III Nabire Papua. Angket adalah alat untuk mengumpulkan data sesuai fakta yang terjadi di lapangan dengan berdasarkan kuestioner atau pertanyaan-pertanyaan dengan tujuan

\footnotetext{
${ }^{6}$ Moh. Nazir, Metode Penelitian, (Jakarta : Ghalia Indonesia, 1988), 212
} 
untuk memperoleh keterangan-keterangan dari masalah yang ingin di teliti. $^{7}$

Ketiga, mengadakan wawancara dengan beberapa anggota jemaat dan juga gembala dari beberapa gereja GKII Daerah III Nabire Papua.

Wawancara adalah proses memperoleh keterangan untuk tujuan penelitian dengan cara Tanya jawab sambil bertatap muka antara si penanya atau pewawancara dengan si penjawab atau responden dengan menggunakan alat yang di namakan interview guide (panduan wawancara).

Kempat, riset perpustakaan dengan mengumpulkan data atau informasi dari buku-buku yang ada di perpustakaan Sekolah Tinggi Teologia Jaffray Makassar serta internet.

\section{Batasan Penulisan}

Demi kelancaran penulisan karya Ilmiah ini, maka penulis membatasi ruang lingkup pembahasan ini yang hanya berfokus pada peranan perempuan dewasa dalam pelayanan gereja, khususnya di GKII Daerah III Nabire Papua.

\footnotetext{
${ }^{7}$ Moh. Nazir, Metode Penelitian, (Jakarta : Ghalia Indonesia, 1988), 245-257

${ }^{8}$ Ibid, 234
} 


\section{METODOLOGI PENELITIAN}

\section{Gambaran Umum Lokasi Survei Kabupaten Nabire}

Nabire adalah salah satu kabupaten yang berada di propinsi Papua yang beribukotakan di Jayapura. Kabupaten Nabire di bentuk pada tahun 1996 sebagai wujud pemekaran Kabupaten dati II Paniai yang di bagi menjadi 3 kabupaten, yaitu: Kabupaten dati II Nabire dengan ibukota Nabire, Kabupaten administratif Paniai dengan ibukota Enarotali dan Kabupaten administratif puncak jaya dengan ibukota Mulia. Luas wilayah Kabupaten Nabire adalah 15.357,55 km2, dan terletak diantara 134,35 BT - 136,37 dan 2,25 LS - 4,15 LS, dengan batas-batas wilayah Kabupaten Nabire sebagai Berikut: sebelah utara kabupaten Yapen dan kabupaten Waropen, sebelah Timur kabupaten Paniai dan kabupaten Waropen, sebelah selatan kabupaten Kaimana dan kabupaten Mimika, sebelah barat teluk wondama dan kabupaten Kaimana. Penduduk masyarakat kabupaten Nabire memeluk agama Kristen Protestan, Kristen Khatolik, Muslim, dan sebagian lagi Hindu dan Budha. Gereja Kemah Injil Indonesia termasuk dalam kelompok Kristen Protestan. Gereja Kemah Injil Indonesia tersebar di beberapa Distrik yang ada di Kabupaten Nabire, beberapa diantaranya berada di pusat kota kabupaten Nabire sedangkan beberapa diantaranya berada jauh di luar pusat kota kabupaten Nabire. Jarak antar Gereja yang satu dengan yang lain berbeda-beda, ada yang berjarak $1 \mathrm{~km}$ dan ada juga yang berjarak 20 sampai $30 \mathrm{~km}$. Gereja Kemah Injil Indonesia daerah III Nabire masuk dalam Wilayah III Papua yang berkantorkan di kabupaten Enarotali.

\section{Sejarah Gereja Kemah Injil Indonesia Daerah III Nabire}

Visi dan Misi serta semangat yang besar, yang ada dalam diri R.A Jaffray telah mengakibatkan masuknya Injil di tanah Papua, khususnya yang ada di pedalaman Papua (Enarotali). Pada tahun 1938 R.A Jaffray berangkat ke Irian Jaya tepatnya di kota Fakfak dan disana ia bertemu dengan W. Cator seorang residen Belanda yang baru kembali dari perjalan megunjungi daerah pedalaman. W. Cator

\footnotetext{
${ }^{9}$ http://www.nabire-destination.com/gambaran-umum-kabupatennabire.html. di akses tgl 5 juli 2011
} 
memberikan motifasi kepada R.A Jaffray untuk juga memenangkan orang-orang Irian Jaya bagi Kristus. ${ }^{10}$

Pada tahun 1938 R.A Jaffray mengutus dua orang C\&MA menuju Irian Jaya melalui Makassar, mereka adalah W.M Post dan Russell Deibler, kedua utusan ini pada akhirnya tiba di danau Wissel daerah Enarotali (Paniai), tepatnya pada tgl 13 Januari 1939 di suku Ekagi atau Ekari. Suku ini lebih senang menyebut diri mereka sebagai orang Me. ${ }^{11}$ Dari daerah inilah penyebaran Injil di daerah Paniai (Papua) di mulai atau awal mulanya berdiri Gereja Kemah Injil Indonesia, yang pada saat itu masih menggunakan nama KINGMIT (Kemah Injil Gereja Masehi Indonesia Timur). ${ }^{12}$ Pada tahun 1960, kantor pusat KINGMI pindah dari Enarotali ke Sentani, akan tetapi pelayanan di Daerah Pania terus belanjut. Dengan berpindahnya kantor pusat KINGMI Papua ke Sentani, maka di sana juga di laksanakan kebaktian bagi orang-orang percaya yang ada di sekitar daerah Sentani, inilah jemaat pertama untuk Daerah pantai Papua. Pada tahun 1977 pelayanan C\&MA menempatkan keluarga Hugland di Nabire tepatnya di Gereja Bethesda untuk membantu pelayanan di sana, hingga pada tahun 1984 telah berdiri enam gereja atau jemaat GKII (KINGMIT) Papua. ${ }^{13}$ Gereja Kemah Injil Indonesia terus mengembangkan pelayanannya di daerah Nabire dan telah membangun beberapa gereja besar dan juga pos PI, akan tetapi tahun 2006 gereja GKII di tanah Papua pecah menjadi dua yaitu gereja GKII dan gereja GKIP dan ini berdampak juga pada pelayanan gereja GKII yang ada di Nabire. Sejak pada tahun 2006 gereja GKIP pisah dari GKII Nabire dan beberapa aset gereja GKII nabire diambil alih oleh GKIP, maka gereja GKII Nabire sendiri membangun gedung gereja sendiri sehingga pada saat ini terhitung sudah ada tujuh belas gereja dan pos PI yang ada di kabupaten Nabire.

\section{Latar Belakang Suku Jemaat}

Dari jumlah gereja GKII yang ada di daerah Nabire, hanya terdapat satu gereja yang jemaatnya terdiri dari beberapa suku yang ada di Indonesia, jemaat itu adalah jemaat Bethesda. Selain dari gereja GKII Jemaat Bethesda, gereja GKII yang lainnya jemaatnya terdiri dari

${ }^{10}$ Rodger Lewis B.A, Karya Kristus di Indonesia, (Bandung: Yayasan Kalam Hidup, 1995), 379,380

${ }^{11}$ Ibid, 381

${ }^{12}$ http://gkiiwilayahpapua.wordpress.com/2008/05/05/sejarah-gereja-kemahinjil-indonesia, di akses 8 juli 2011

${ }^{13}$ Rodger Lewis B.A, Karya Kristus di Indonesia, (Bandung: Yayasan Kalam Hidup, 1995), 461-463 
suku Ekari atau Me, Moni, dan Dani. Suku-suku ini banyak tersebar di daerah tanah papua khsususnya di pedalaman Papua Enarotali dan sekitarnya. Gereja GKII di Nabire boleh di katakan sebagai gereja suku, karena jika kita melihat di sana ada terjadi pengelompokanpengelompokan suku. Jika gembalanya dari suku Ekari atau Me, maka semua jemaatnya juga dari suku Ekari atau suku Me, demikian sebaliknya jika gembalanya dari suku Dani dan Moni maka jemaatnya juga demikian. ${ }^{14}$

\section{Fakta Keterlibatan Perempuan Dalam Pelayanan GKII Nasional dan Nabire}

Berdasarkan pengalaman dari penulis selama ber-KKL di gereja GKII Jemaat Bethesda Nabire selama enam bulan, penulis menemukan ada masalah yang terjadi dalam pelayanan di gereja GKII daerah Nabire yang berhubungan dengan perempuan. Di beberapa gereja GKII Nabire menolak atau tidak mengijinkan perempuan terlibat dalam pelayanan di gereja baik berkhotbah, memimpin pujian (WL), memimpin doa, ataupun berbicara saat peretemuan-pertemuan jemaat, akan tetapi pada faktanya gereja GKII secara Nasional terbuka terhadap setiap keterlibatan perempuan dalam gereja, dalam arti bahwa gereja GKII juga memberikan kesempatan kepada kaum perempuan untuk dapat turut mengambil bagian dalam pelayanan-pelayanan apa saja di gereja GKII, sesuai dengan karunia yang di berikan Allah kepada kaum perempuan. Di kalangan gereja GKII, hanya di Nabire sajalah ada gereja GKII yang tidak menerima perempuan untuk terlibat dalam pelayanan di gerejaialah; gereja GKII Jemaat Zion. Hal ini menjadi pergumulan tersendiri bagi gereja GKII yang ada di Nabire dan juga secara Nasional. Keadaan perempuan gereja GKII Nabire mengalami tekanan sebab mereka dilarang untuk melayani di gereja, hanya pada beberapa gereja atau jemaat perempuan memiliki peranan dalam pelayanan gereja, diantaranya ada yang menjadi majelis, guru sekolah minggu, menjadi pelatih paduan suara, dan pemimpin pujian (WL), gerejagereja tersebut adalah gereja GKII jemaat Bethesda, jemaat Kalimangga, jemaat Getsemani, jemaat Anugerah dan jemaat Laodekia. Gereja-gereja tersebut memberikan kesempatan kepada perempuan untuk melayani.

\footnotetext{
${ }^{14}$ Mozes Sabandar, Wawancara oleh Penulis. Nabire 13 juni 2011
} 


\section{Jenis Penelitian}

Untuk mendapatkan data dan informasi yang berhubungan dengan penulisan karya ilmiah ini, maka penulis menggunakan beberapa metode atau jenis penilitian, sebagai berikut:

Pertama, mengadakan observasi atau pengamatan lapangan yaitu di Gereja Kemah Injil Indonesia daerah III Nabire Papua. "Observasi adalah cara pengambilan data dengan menggunakan mata tanpa ada pertolongan alat standar untuk keperluan tersebut". ${ }^{15}$

Kedua, mengedarkan angket kepada beberapa anggota gereja kemah injil Daerah III Nabire Papua. Angket adalah alat untuk mengumpulkan data sesuai fakta yang terjadi di lapangan dengan berdasarkan kuestioner atau pertanyaan-pertanyaan dengan tujuan untuk memperoleh keterangan-keterangan dari masalah yang ingin di teliti. $^{16}$

Ketiga, mengadakan wawancara dengan beberapa anggota gembala. Wawancara adalah proses memperoleh keterangan untuk tujuan penelitian dengan cara Tanya jawab sambil bertatap muka antara si penanya atau pewawancara dengan si penjawab atau responden dengan menggunakan alat yang di namakan interview guide(panduan wawancara). ${ }^{17}$

Keempat, riset perpustakaan dengan mengumpulkan data atau informasi dari buku-buku yang ada di perpustakaan Sekolah Tinggi Teologia Jaffray Makassar serta internet.

\section{Populasi dan Sampel}

Populasi dan sampel merupakan faktor yang sangat di perlukan untuk memperoleh data dalam suatu penelitian.

\section{Populasi}

"Populasi adalah seluruh jumlah orang atau penduduk di suatu daerah atau sekelompok orang, benda, atau hal yang menjadi sumber pengambilan sampel; suatu kumpulan yang memenuhi syarat tertentu yang berkaitan dengan masalah penelitian".

Dalam penulisan karya ilmiah ini populasi yang akan di teliti adalah warga jemaat dewasa dari gereja GKII Jemaat Bethesda dan

\footnotetext{
${ }^{15}$ Moh. Nazir, Metode Penelitian, (Jakarta : Ghalia Indonesia, 1988), 212

${ }^{16}$ ibid, 245-257

${ }^{17}$ Ibid, 234

${ }^{18}$ Kamus Besar Bahasa Indonesia, (Jakarta: Balai Pustaka, 2001), 889
} 
Jemaat Petrus Kalimangga Daerah Nabire. Jumlah keseluruhan gereja dan pos PI GKII yang ada di nabire seluruhnya adalah 14, dan jemaat dewasanya berjumlah 1085 jemaat hingga tahun 2011 ini, sedangkan jumlah anggota perkawan seluruhnya berjumlah 503. Data ini di peroleh dari sekretaris gereja GKII daerah Nabire. ${ }^{19}$

\section{Sampel}

Sampel adalah sesuatu yang di gunakan untuk menunjukan sifat suatu kelompok yang lebih besar. ${ }^{20}$ Dalam penulisan karya ilmiah ini, yang di jadikan sebagai sampel yang akan di teliti adalah jemaat dewasa dari gereja GKII jemaat Bethesda dan gereja GKII jemaat Petrus Kalimangga yang jumlah jemaat dewasanya adalah 276 dengan perincian yaitu jemaat Bethesda 236 jemaat dewasa baptis dan jemaat Petrus Kalimangga 40 jemaat dewasa baptis.

\section{Teknik Pengumpulan Data}

Dari penelitian ini karya ilmia ini penulis menggunakan teknik pengumpulan melalui:

Pertama, Angket adalah alat untuk mengumpulkan data sesuai fakta yang terjadi di lapangan dengan berdasarkan kuestioner atau pertanyaan-pertanyaan dengan tujuan untuk memperoleh keteranganketerangan dari masalah yang ingin di teliti. ${ }^{21}$ Tujuan pokok dari pembuatan kuesioner adalah (a) memperoleh informasi yang relevan dengan tujuan survey, dan (b) memperoleh informasi dengan reliabitas dan validitas setinggi mungkin. ${ }^{22}$

Kedua, Wawancara adalah proses memperoleh keterangan untuk tujuan penelitian dengan cara Tanya jawab sambil bertatap muka antara si penanya atau pewawancara dengan si penjawab atau responden dengan menggunakan alat yang di namakan interview guide (panduan wawancara). ${ }^{23}$

Ketiga, Kepustakaan (Literatur) adalah metode yang di gunakan penulis untuk mengumpulkan data atau informasi dari buku-buku perpustakaan dan dari bahan-bahan penulisan karya ilmiah lainnya

\footnotetext{
${ }^{19}$ Mozes Sabandar, Wawancara Oleh Penulis. Nabire 13 juni 2011

${ }^{20}$ Kamus Besar Bahasa Indonesia, (Jakarta: Balai Pustaka, 2001), 991

${ }^{21}$ Moh. Nazir, Metode Penelitian, (Jakarta : Ghalia Indonesia, 1988) ,245-257

${ }^{22}$ Masri Singarimbun-Tri Handayani, Metode Penelitian Survey, (jakarta: LP3ES, 1985), 130

${ }^{23}$ Moh. Nazir, Metode Penelitian, (Jakarta : Ghalia Indonesia, 1988), 234
} 
serta internet yang ada kaitannya dengan pokok-pokok bahasan dari karya ilmiah ini sebagai suatu landasan teori dan teologi.

Observasi lapangan, "Observasi adalah cara pengambilan data dengan menggunakan mata tanpa ada pertolongan alat standar untuk keperluan tersebut". ${ }^{24}$

\section{Teknik Analisis Data}

Untuk mendapatkan hasil analisis yang baik, dalam menganalisis data yang telah di kumpulkan, mengenai peranan perempuan di gereja GKII daerah III Nabire Papua, dengan demikian penulis membutukan metode atau rumus dalam menganalisis data yang telah di kumpulkan itu. Penulis menganalisis data yang terkumpul, dengan menggunakan rumus di bawah ini:

$\frac{N}{M} \times 100=\%$

Keterangan:

$\%=$ persentase

$\mathrm{N}=$ Jumlah jawaban responden

$\mathrm{M}=$ jumlah responden $^{25}$

\footnotetext{
${ }^{24}$ Ibid, 212

${ }^{25}$ Muh Ali, Penelitian Kependidikan (Bandung: Angkasa, 1981), 184
} 


\section{ANALISIS HASIL PENELITIAN DAN PEMBAHASAN}

\section{Analisis Wawancara}

Dalam penelitian ini, penulis melakukan wawancara dengan 3 (tiga) orang gembala, dan 1 (satu) orang jemaat yang juga sebagai penasehat gereja GKII wilayah III Papua. Dari wawancara tersebut diperoleh data bagaimana peranan perempuan dalam mengembangkan pelayanan di gereja GKII daerah III Nabire Papua.

Hasil penelitian tersebut dibahas pada bagian ini dengan menganalisa berdasarkan respon atau jawaban yang di dapat dari beberapa pertanyaan wawancara, yang diajukan oleh penulis sehubungan dengan judul yang dipilih. Selanjutnya penulis membandingkannya dengan peranan perempuan, dalam mengembangkan pelayanan gereja secara substansial dan menguraikannya berdasarkan pada teori pelayanan perempuan, sehingga terdapat kesinambungan antara teori dan praktek yang diperjelas dalam sebuah kesimpulan.

Pada tanggal 06 juni 2011 penulis berangkat ke Nabire untuk mengadakan penelitian lapangan, dengan di sertai surat keterangan atau rekomendasi penelitian dari Sekolah Tinggi Teologia Jaffaray Makassar. Wawancara adalah salah satu metode yang digunakan penulis dalam penelitian penulisan karya Ilmiah ini. Wawancara dilakukan melalui telepon dan bertatap muka dengan beberapa gembala dan juga jemaat. Tepatnya pada tanggal 13 dan 14 juni 201l, penulis mengadakan wawancara secara langsung dengan narasumber di kediaman atau tempat tinggal mereka masing-masing; diantaranya dalam kondisi dan keadaan yang sehat serta tenang, diantaranya;

\section{Pendeta Rowi Radja}

Beliau adalah alumni mahasisiwa STT Jaffray Makassar dan saat ini menjadi gembala sidang di gereja GKII jemaat Bethesda Nabire. Jawaban atau respon yang di berikan oleh bapak pendeta Rowi Radja dari pertanyaan yang di ajukan (lihat Lampiran) penulis mengenai peranan perempuan. Pendeta Rowi Radja berkata, bahwa

"seorang perempuan sah-sah saja untuk menjadi pelayan baik sebagai gembala, majelis, dan juga pengkhotbah, dengan alasan bahwa di Alkitab juga terdapat nabiah seperti Debora dan Myriam dan juga beberapa pelayan perempuan dalam perejanjian baru yaitu Febe, Priskila, Trifosa dan Trifena (Roma pasal 16). Di Jemaat yang saya gembalakan ada terdapat majelis dan guru sekolah minggu perempuan dan mereka juga sering berkhotbah dan 
memimpin ibadah serta doa dalam ibadah-ibadah jemaat, dan hal ini sangatlah membantu pelayanan kami di gereja."

Pendeta Mozes Sabandar,

Beliau adalah alumni mahasiwa Sekolah Tinggi Teologia Jaffaray

Makassar dan sekarang ini menjadi wakil gembala sidang di gereja GKII jemaat Bethesda Nabire. Pendeta Mozes Sabandar berkata, bahwa

"untuk menjadi seorang pelayan Tuhan tidaklah ditentukan berdasarkan jenis kelamin. Perempuan boleh-boleh saja perempuan untuk melayani dalam hal ini menjadi gembala, majelis atau berkhotba, dengan alasan bahwa Allah tidak hanya memberikan karunia untuk melayani kepada laki-laki saja, melainkan Allah juga memberikan karunia itu kepada kaum perempuan. Di Alkitab juga ada perempuan sebagai nabiah dan nabiah ini dipilih langsung oleh Allah, dengan demikian di mata Allah laki-laki maupun perempuan sama saja. Di jemaat yang saya gembalakan ada terdapat guru sekolah minggu dan juga majelis perempuan dan mereka sering memimpin doa dan berkhotbah serta memimpin ibadah-ibadah (WL) dalam ibadah jemaat, dan ada juga yang melatih paduan suara. Keterlibatan mereka cukup membantu pelayanan kami di jemaat." 27

\section{Bapak Yopie Udimeraa}

Beliau adalah penasehat Wilayah III Papua yang saat ini berdomisili di kabupaten Nabire sebagai jemaat dan juga majelis di gereja GKII jemaat Bethesda Nabire. Bapak Yopie Udimeraa berpendapat, bahwa

"perempuan bisa melayani di gereja baik sebagai pendeta ataupun majelis, asal saja mereka benar-benar terpanggil untuk pelayanan ini, karena saya yakin semua orang Kristen yang lahir baru, juga dipanggil untuk melayani. Di jemaat kami ada perempuan yang jadi majelis dan itusangat membantu." 28

\section{Pendeta Kalolik Antarikus Kalolik}

Pendeta Kalolik Antarikus adal gembala sidang di gereja GKII Jemaat Petrus Kalimangga Nabire. Pendeta Antarikus kalolik di

\footnotetext{
${ }^{26}$ Pdt Rowi Radja, Wawancara oleh Penulis. Nabire 13 juni 2011

${ }^{27}$ Pdt Mozes Sabandar, Wawancara oleh Penulis. Nabire 13 juni 2011

${ }^{28}$ Bapak Yopie Udimeraa, Wawancara Oleh Penulis. Nabire 14 juni 2011 
wawancara oleh penulis melalui via telepon pada tanggal 30 juli 2011. Dari pertanyaan yang di sampaikan oleh penulis kepada bapak Pdt Antarikus Kalolik mengenai peranan perempuan;

"Pdt Antarikus Kalolik berpendapat bahwa perempuan bisa saja menjadi pelayan Tuhan di gereja, hal itu tidak jadi masalah, karena itu bukanlah standart atau syarat untuk orang di selamatkan dan Allah juga memanggil perempuan untuk melayani. Di gereja saya yang lebih banyak berperan adalah perempuan, mereka menjadi majelis, memimpin pujian, dan juga mengajar sekolah minggu. Peranan perempuan di gereja kami sangatlah membantu."${ }^{29}$

Dari hasil wawancara di atas dapat dikatakan bahwa sesungguhnya perempuan dapat menjadi pelayanan Tuhan dengan catatan bahwa jika mereka benar-benar terpanggil dalam pelayanan yang khusus ini. Dapat juga di katakan bahwa menjadi seorang pelayan itu tidaklah di tentukan berdasarkan jenis kelamin, siapa saja dapat menjadi pelayan. Para narasumber di atas menyadari betapa pentingnya perempuan terlibat dalam pelayanan di gereja karena hal itu merupakan sebuah sumbangsi yang cukup membantu dalam pelayanan di gereja.

${ }^{29}$ Pendeta Antarikus Kalolik, Wawancara oleh Penulis. Makassar 30 juli 2011 


\section{Analisa Angket}

Tabel 01:

Peranan Perempuan Dalam Gereja GKII Nabire

\begin{tabular}{|c|c|c|c|c|c|c|c|c|}
\hline \multirow{2}{*}{$\begin{array}{c}\text { PER } \\
\text { TANYAAN }\end{array}$} & \multicolumn{2}{|c|}{ ya } & \multicolumn{2}{|c|}{ tidak } & \multicolumn{2}{|c|}{$\begin{array}{l}\text { Tidak } \\
\text { tahu }\end{array}$} & \multicolumn{2}{|c|}{ jumlah } \\
\hline & $\mathrm{N}$ & $\%$ & $\mathrm{~N}$ & $\%$ & $\mathrm{~N}$ & $\%$ & $\mathrm{M}$ & $\%$ \\
\hline $\begin{array}{l}\text { Apakah ada pendeta } \\
\text { atau gembala } \\
\text { perempuan di gereja } \\
\text { anda? }\end{array}$ & 0 & $0 \%$ & 121 & $\begin{array}{l}100 \\
\%\end{array}$ & 0 & & 121 & $100 \%$ \\
\hline $\begin{array}{l}\text { Apakah ada } \\
\text { perempuan yang } \\
\text { memimpin pujian } \\
\text { (WL) dalam Ibadah } \\
\text { Jemaat, di gereja } \\
\text { anda? }\end{array}$ & $\begin{array}{l}11 \\
9\end{array}$ & $\begin{array}{l}98 \\
\%\end{array}$ & 2 & $2 \%$ & 0 & $\%$ & 121 & $100 \%$ \\
\hline $\begin{array}{l}\text { Apakah ada } \\
\text { perempuan yang } \\
\text { berkhotbah di } \\
\text { gereja anda? }\end{array}$ & $\begin{array}{l}11 \\
2\end{array}$ & $\begin{array}{l}93 \\
\%\end{array}$ & 5 & $4 \%$ & 4 & $\begin{array}{l}3 \\
\%\end{array}$ & 121 & $100 \%$ \\
\hline
\end{tabular}

Dari tabel 01 di atas, menggambarkan bagaimana keterlibatan perempuan dalam pelayanan di gereja GKII daerah III Nabire. Dari jawaban responden di tiap-tiap pertanyaan, sebagian besar mengatakan bahwa perempuan juga turut mengambil bagian dalam pelayanan, hanya pada pertanyaan pertama terlihat bahwa, di gereja GKII Nabire tidak ada pendeta atau gembala perempuan, terlihat dari persentase di atas dari jumlah keseluruhan responden menjawab tidak. Sedangkan pada pertanyaan ke-2 dan ke-3 terlihat jelas betapa besar persentasenya tentang keterlibatan perempuan, walaupun ada $2 \%$ yang menjawab tidak pada pertanyaan ke-2 dan ada $4 \%$ yang berkata tidak serta 3\% yang berkata tidak tahu pada pertanyaan ke-3. Dari persentase tabel 0l, dapat di katakan bahwa sesungguhnya perempuan di gereja GKII Nabire sangatlah aktif dalam pelayaanan di gereja, walaupun tidak ada pendeta atau gembala perempuan di gereja GKII Nabire. 
Tabel 02 :

Tanggapan Jemaat Terhadap Peranan Perempuan Dalam Gereja

\begin{tabular}{|c|c|c|c|c|c|c|c|c|}
\hline \multirow{2}{*}{$\begin{array}{ll} & \text { PERTANYAA } \\
\mathrm{N} & \end{array}$} & \multicolumn{2}{|r|}{ ya } & \multicolumn{2}{|c|}{$\begin{array}{l}\text { tida } \\
\mathrm{k}\end{array}$} & \multicolumn{2}{|c|}{$\begin{array}{l}\text { Tidak } \\
\text { tahu }\end{array}$} & \multicolumn{2}{|c|}{$\begin{array}{l}\text { jumla } \\
\mathrm{h}\end{array}$} \\
\hline & $\mathrm{N}$ & $\%$ & $\mathrm{~N}$ & $\%$ & $\mathrm{~N}$ & $\%$ & $\mathrm{M}$ & $\%$ \\
\hline $\begin{array}{l}\text { Apakah anda setuju } \\
\text { jika perempuan } \\
\text { menjadi pendeta / } \\
\text { gembala? }\end{array}$ & 101 & $83 \%$ & 20 & $\begin{array}{l}17 \\
\%\end{array}$ & 0 & $0 \%$ & 121 & $\begin{array}{l}100 \\
\%\end{array}$ \\
\hline $\begin{array}{l}\text { Apakah anda setuju } \\
\text { jika perempuan } \\
\text { memimpin pujian } \\
\text { (WL) dalam ibadah } \\
\text { jemaat? }\end{array}$ & 119 & $98 \%$ & 0 & $0 \%$ & 2 & $2 \%$ & 121 & $\begin{array}{c}100 \\
\%\end{array}$ \\
\hline $\begin{array}{l}\text { Apakah anda setuju } \\
\text { jika perempuan } \\
\text { menjadi majelis? }\end{array}$ & 117 & $97 \%$ & 4 & $3 \%$ & 0 & $0 \%$ & 121 & $\begin{array}{c}100 \\
\%\end{array}$ \\
\hline $\begin{array}{l}\text { Apakah anda setuju } \\
\text { jika perempuan } \\
\text { berkhotba dalam } \\
\text { ibadah jemaat? }\end{array}$ & 105 & $87 \%$ & 10 & $8 \%$ & 6 & $5 \%$ & 121 & $\begin{array}{c}100 \\
\%\end{array}$ \\
\hline $\begin{array}{l}\text { Apakah anda yakin } \\
\text { jika perempuan dan } \\
\text { laki-laki bekerja } \\
\text { sama dalam } \\
\text { pelayanan, maka } \\
\text { pelayanan itu akan } \\
\text { efektif? }\end{array}$ & 100 & $83 \%$ & 0 & $0 \%$ & 21 & $\begin{array}{l}17 \\
\%\end{array}$ & 121 & $\begin{array}{c}100 \\
\%\end{array}$ \\
\hline
\end{tabular}

Dalam tabel 02, kita melihat bahwa jemaat GKII Nabire sebagian besar setuju jika perempuan terlibat dalam semua lini pelayanan gereja. Hanya sebagian orang atau para responden tidak setuju jika perempuan terlibat dalam pelayanan gereja sebagai Pendeta, Gembala, dan pengkhotba dan ada yang berkata tidak tahu. Kita lihat pada persentase di tiap-tiap pertanyaan. Pada pertanyaan pertama $83 \%$ yang setujuh dan $17 \%$ yang tidak setuju.Pada pertanyaan kedua $98 \%$ setuju 
dan $2 \%$ berkata tidak tahu. Dalam pertanyaan yang ketiga persentasenya $87 \%$ yang setuju, $8 \%$ tidak setuju, dan $5 \%$ berkata tidak tahu. Sedangkan pada pertanyaan keempat kita juga melihat 83\% responden setuju dan 17\% lainnya berkata tidak tahu. Dari adanya persentase ini kita melihat bahwa ada juga para responden, yang jika di rata-ratakan berjumlah 20\% yang tidak setuju jika perempuan itu ikut terlibat dalam pelayanan, baik itu sebagai gembala, majelis, dan pemimpin pujian (WL). Hal ini menjadi pergumulan besar bagi para pemimpin gereja GKII untuk bagaimana meyakinkan dan menjelaskan bahwa perempuan dapat terlibat dalam pelayanan gereja.

Tabel 03 :

Pandangan Jemaat Terhadap Karunia

\begin{tabular}{|l|c|c|c|c|c|c|c|c|}
\hline \multirow{2}{*}{ PERTANYAA } & \multicolumn{2}{|c|}{ Ya } & \multicolumn{2}{c|}{ Tidak } & \multicolumn{2}{c|}{$\begin{array}{c}\text { Tidak } \\
\text { Tahu }\end{array}$} & \multicolumn{2}{c|}{ Jumlah } \\
\cline { 2 - 8 } N & $\mathrm{N}$ & $\%$ & $\mathrm{~N}$ & $\%$ & $\mathrm{~N}$ & $\%$ & $\mathrm{M}$ & $\%$ \\
\hline $\begin{array}{l}\text { Apakah anda yakin } \\
\text { bahwa Allah juga } \\
\text { memberikan karunia } \\
\text { kepada perempuan }\end{array}$ & 117 & $97 \%$ & 0 & $0 \%$ & 4 & $3 \%$ & 121 & $\begin{array}{c}100 \\
\%\end{array}$ \\
\hline $\begin{array}{l}\text { Apakah anda yakin } \\
\text { jika perempuan juga } \\
\text { memiliki } \\
\text { keunggulan dari } \\
\text { laki-laki }\end{array}$ & 101 & $83 \%$ & 0 & $0 \%$ & 20 & 17 & 121 & $\begin{array}{c}100 \\
\%\end{array}$ \\
\hline $\begin{array}{l}\text { Apakah anda yakin } \\
\text { bahwa perempuan } \\
\text { dan laki-laki } \\
\text { memiliki kesamaan } \\
\text { karunia? }\end{array}$ & 110 & $91 \%$ & 5 & $4 \%$ & 6 & $5 \%$ & 121 & $\begin{array}{c}100 \\
\%\end{array}$ \\
\hline
\end{tabular}

Pada tabel 03 kita bisa melihat jawaban dari responden di tiaptiap pertanyaan yang berhubungan dengan karunia. Pada pertanyaan pertama kita lihat persentasenya 97\% responden menjawab ya, 3\% lagi menjawab tidak tahu dan secara mengejutkan kita lihat pada pertanyaan ke-2, para responden mengakui bahwa perempuan juga memiliki keunggulan dari para kaum laki-laki, terlihat dari persentase yaitu $83 \%$, dan pada pertanyaan ke-3 para responden juga mengakui bahwa ada persamaan karunia yang di berikan Allah kepada manusia 
baik laki-laki dan perempuan dengan persentase 91\%. Dari adanya keterangan ini, kita lihat bahwa jemaat di gereja GKII Daerah III Nabire sebagian besar mengakui adanya karunia yang dimiliki oleh kaum perempuan dan perempuan juga memiliki kelebihan dari kaum laki-laki, inilah keunggulan perempuan.

\section{Faktor Penghambat Terhadap Pelayanan Perempuan GKII Daerah III Nabire}

Pelayanan kaum perempuan di gereja GKII Daerah III Nabire terbilang biasa-biasa saja dan bahkan hampir tidak terlihat, karena ada faktor penghambat yang menghambat cepatnya kemajuan pelayanan kaum perempuan, akan tetapi di beberapa gereja GKII Daerah III Nabire masih terlihat peran perempuan di gereja. Faktor-faktor yang menghambat kemajuan pelayanan perempuan GKII Daerah III Nabire adalah:

\section{Pengaruh Ajaran Misi Tempo Dulu}

Melihat sejarah GKII mengenai masuknya injil ke tanah Papua yang di bawa oleh para Misi CAMA yang pertama, salah satu ajaran mereka adalah mengenai perempuan tidak diijinkan untuk tampil sebagai pengkhotbah atau berbicara di hadapan para kaum laki-laki. Hal inilah yang menjadi alasan atau faktor yang menghambat pelayanan perempuan dalam gereja yang ada di Nabire. Beberapa gereja GKII Daerah III Nabire dan termasuk ketua daerah Nabire masih memegang pemahaman yang dibawa oleh MISI CAMA hingga sekarang ini, sehingga para kaum perempuan masih enggan untuk secara terang-terangan melakukan pelayanan mereka di jemaat. Menurut mereka perempuan yang berbicara atau berkhotbah di hadapan para kaum laki-laki merupakan sebuah pelanggaran karena Alkitab tidak mengijinkan perempuan untuk berbicara dan berkhotba di depan para laki-laki. ${ }^{30}$

\section{Pengaruh Budya}

Budaya adalah salah satu faktor penghambat, mengapa pelayanan perempuan dalam gereja di GKII Daerah III Nabire tidak terlihat atau dengan kata lain tidak maju atau biasa-biasa saja. Seperti halnya dalam pembahasan sebelum mengenai perempuan dalam budaya Papua, bahwa perempuan merupakan kaum yang bekerja untuk laki-laki.

\footnotetext{
${ }^{30}$ Mozes Sabandar, Wawancara oleh Penulis. Nabire 13 juni 2011
} 
Perempuan adalah orang nomor dua dalam budaya Papua dan bahkan Pastor J. Budihernawan OFM mengatakan bahwa sesungguh "perempuan Papua itu tidak ada", dengan kata lain perempuan adalah kaum yang kurang atau tidak diperhitungkan dalam budaya Papua. Karena adanya pengaruh budaya yang dipadukan dengan pemahaman Alkitab yang kurang mendalam yang menyebabkan orang Papua khususnya para kaum laki-laki yang ada di daerah Nabire tidak bisa menerima perempuan untuk memimpin atau tampil sebagai pengkhotbah, karena hal itu merupakan pelanggaran adat.

\section{Pemahaman yang Berbeda Dalam Organisasi GKII}

Pemahaman yang berbeda dalam sebuah organisasi dapat mengakibatkan kekacauan dalam organisasi tersebut. Di sinilah diperlukan sosialisasi mengenai ajaran dan pemahaman kepada setiap anggota dalam organisasi tersebut, demi menciptakan sebuah organisasi yang sehati dan baik pada pandangan orang, dan terlebih lagi agar ada keseragaman dalam menerapkan asas-asas yang ada dalam organisasi tersebut. Hal inilah yang kurang dalam organisasi di gereja GKII. Adanya perbedaan pemahaman mengenai ajaran yang berhubungan dengan keterlibatan perempuan dalam pelayanan gereja, telah mengakibatkan terciptanya kubu-kubu di kalangan gereja GKII, khususnya di Nabire. Di Nabire sangatlah berbeda pemahamannya mengenai perempuan jika dibandingkan dengan gereja-gereja GKII di beberapa kota di Indonesia. Beberapa gembala dan anggota jemaat dari gereja GKII yang ada di Nabire menolak perempuan untuk terlibat dalam pelayanan gereja sedangkan gereja-gereja GKII di kota-kota lain dapat menerima perempuan untuk melayani.

\section{Solusi}

Dengan adanya faktor penghambat di atas maka kita harus dapat memberikan solusi yang dapat memberikan jalan keluar untuk mengatasi faktor penghambat di atas, diantaranya;

Pertama, Para anggota misi C\&MA masa ini haruslah mensosialisakan ajaran mereka sesuai dengan ajaran organisasi GKII yang ada di Indonesia, serta mensosialisasikannya kepada jemaat di gereja GKII Daerah III Nabire papua demi mendapatkan kesamaan pemahaman dengan gereja GKII se-Indonesia.

Kedua, Yang harus diterapkan oleh jemaat gereja GKII daerah III Nabire adalah mengedepankan Firman Tuhan dan bukan budaya, 
dalam artian jemaat harus lebih mengikuti Firman Tuhan dan bukan Budaya. Budaya harus di sesuaikan dengan Firman Tuhan.

Ketiga, Para pimpinan gereja GKII harusnya mensosialisasikan ajaran dan doktrin yang di pegang oleh organisasi gereja GKII saat ini, demi mendapatkan suatu pemahaman yang sama dalam lingkungan gereja GKII.

\section{PENUTUP}

Setelah menguraikan secara panjang lebar mengenai peranan Perempuan dalam mengembangkan pelayanan di gereja GKII Daerah III Nabire Papua, maka pada bagian penutup ini, penulis memberikan beberapa kesimpulan dan saran-saran.

\section{Kesimpulan}

Adapun yang menjadi kesimpulan dari penulisan karya ilmiah ini adalah: Pertama, tidak semua gereja atau jemaat yang ada di gereja GKII Daerah III Nabire, menolak perempuan untuk terlibat dalam pelayanan di gereja, hanya ada di gereja tertentu saja yang menolak perempuan untuk melayani di gereja. Kedua, perempuan di gereja GKII Daerah III Nabire, sangatlah berperan aktif dalam pelayanan, hanya saja belum secara terang-terangan para kaum perempuan memperlihatkan pelayanan mereka, sebab masih ada yang menentang tindakan mereka. Ketiga, di gereja GKII Daerah III Nabire, ada di jemaat-jemaat tertentu, ada bentuk peran perempuan yang terlihat, diantaranya; Majelis, pemimpin pujian (WL), dan guru sekolah minggu. Keempat, perempuan juga adalah bagian dari tubuh Kristus, karena itu perempuan juga, diberikan karunia oleh Allah untuk melayani Dia dalam membangun tubuh Kristus yaitu gereja yang sehat dan bertumbuh. Kelima, laki-laki dan perempuan sama-sama menjadi ciptaan Allah, yang diciptakan menurut gambar dan rupa Allah, karena itu diantara keduanya tidak ada perbedaan di hadapan Allah, keduanya sama. Keenam, laki-laki dan perempuan sama-sama diberikan mandate atau otoritas oleh Allah atas alam ciptaan-Nya (Kej 1:28).

\section{Saran-Saran}

Dalam mewujudkan peran serta perempuan dalam mengembangkan pelayanan di gereja, maka para pemimpin dan jemaat GKII Daerah III Nabire harus terbuka dan melibatkan perempuan dalam pelayanan gereja. Sehubungan dengan peranan perempuan, 
maka penulis memberikan saran-saran kepada para pemimpin dan jemaat serta para kaum perempuan sebagai berikut: Pertama, hendaknya para pemimpin gereja dan jemaat serta perempuan gereja GKII daerah III Nabire dapat bekerjasama demi membangun pelayanan gereja yang lebih baik. Kedua, hendaknya para pemimpin gereja GKII Daerah III Nabire lebih meningkatkan kualitas penafsiran Alkitab dan meningkatkan pendidikannya, sehingga tidak tercipta perbedaan penafsiran Alkitab. Ketiga, hendaknya para pemimpin gereja dapat terus mengembangkan karunia dari kaum perempuan dengan cara melibatkan mereka dalam seluruh aspek pelayanan gereja. Keempat, hendaknya para kaum perempuan dapat melibatkan diri secara lebih aktif lagi dalam pelayanan gereja, sehingga pelayanan gereja akan menjadi lebih efektif dan baik. Kelima, hendaknya para pemimpin gereja dan jemaat lebih mengedepankan prinsip-prinsip Firman Tuhan dan bukan budaya atau, tidak terjadi kekacauan dalam pelayanan gereja. 


\section{KEPUSTAKAAN}

\section{Alkitab dan Buku}

Alkitab Jakarta, Lembaga Alkitab Indonesia, 2006.

Kamus Besar Bahasa Indonesia, Jakarta: Balai Pustaka, 2001.

Ali, Muh. Penelitian Kependidika. Bandung: Angkasa, 1981.

Boice, James Montogomery. Dapatkah Aku dipakai Allah Bandung : Kalam Hidup, 1982.

Kaunang, Kapahang Perempuan: Pemahaman Teologis Tentang Perempuan Dalam Konteks Budaya MInahasa. Jakarta: BPK Gunung Mulia, 1993.

Lewis B.A, Rodger. Karya Kristus di Indonesia. Bandung: Yayasan Kalam Hidup, 1995.

Nazir, Moh. Metode Penelitian. Jakarta : Ghalia Indonesia, 1988.

Singarimbun, Masri dan Tri Handayani, Metode Penelitian Survey. Jakarta: LP3ES, 1985.

\section{Internet}

http://gkiiwilayahpapua.wordpress.com/2008/05/05/sejarah-gerejakemah-injil-indonesia, di akses 8 juli 2011

http://www.nabire-destination.com/gambaran-umum-kabupatennabire.html. di akses tgl 5 juli 2011

\section{Wawancara}

Kalolik, Antarikus. Wawancara oleh Penulis. Makassar 30 juli 2011. Radja, Rowi. Wawancara oleh Penulis. Nabire 13 juni 2011.

Sabandar, Mozes. Wawancara oleh Penulis. Nabire 13 juni 2011.

Udimeraa, Yopie. Wawancara Oleh Penulis. Nabire 14 juni 2011. 